\title{
PENAMPILAN PRODUKSI TERNAK BABI GROWER YANG MENGGUNAKAN TEPUNG KULIT KOPI SEBAGAI BAHAN PENGGANTI SEBAGIAN DEDAK HALUS PADA PAKAN
}

\author{
Mardo C Timbulus, Petrus R.R.I Montong*, Arie Dp. Mirah, S.E. Siswosubroto \\ Fakultas Peternakan Universitas Sam Ratulangi, Manado 95115
}

\begin{abstract}
ABSTRAK
Aneka bahan pakan atau limbah yang belum dimanfaatkan misalnya kulit buah kopi dapat menjadi bahan pakan alternatif sumber serat kasar melihat kandungannya dalam kulit buah kopi yakni $33,60 \%$. Sulawesi Utara khususnya Bolaang Mogondow yang merupakan sentra perkebunan kopi, memiliki luas perkebunan 4.009,07 ha, dengan produksi kopi mencapai 2.135,46 ton bahan mentah yang belum dipisahkan antara buah kopi dengan daun dan batangnya. Setelah dipisah didapat buah kopi sebanyak 1.281,22 ton pertahun. Buah kopi diolah untuk memisahkan antara biji dan kulitnya setelah dipisahkan diperoleh kulit buah kopi sebanyak 448.449 ton. Penampilan produksi dengan melihat pertambahan berat badan, jumlah konsumsi dan efisiensi penggunaan pakan adalah bagian dari perrsyaratan untuk melihat kemampuan produksi ternak babi. Penelitian dilaksanakan selama 66 hari terdiri dari 52 hari periode pengumpulan data dan 2 minggu preliminary collecting data bertujuan untuk mengetahui pengaruh penggunaan kulit kopi sebgai pengganti sebagian dedak halus terhadap penampilan produksi dari ternak babi fase grower sampai finisher. Penelitian menggunakan 16 ekor babi jantan dan betina periode grower berumur 12 - 16 minggu keturunan jenis Yorkshire dan Landrace. Rancangan acak kelompok dengan 4 level perlakuan
\end{abstract}

*Korespondensi (corresponding author): Email: richard_montong@unsrat.ac.id yaitu $0,25 \%, 50 \%, 75 \%$ kulit kopi sebagai pengganti sebagian dedak halus pada 4 kelompok berat badan yang berbeda sebagai ulangan. Hasil analisis sidik ragam (ANOVA) menunjukkan pemberian tepung kulit kopi sebagai pengganti sebagian dedak halus terhadap pertambahan berat badan memberikan pengaruh nyata $(\mathrm{P}<0,05)$, jumlah konsumsi pakan tidak memberikan pengaruh nyata $(\mathrm{P}>0,05)$, dan efisiensi penggunaan paka memberikan pengaruh nyata $(\mathrm{P}<0,05)$. Penggunaan tepung kulit kopi sebgai pengganti sebagian dedak halus pada ternak babi grower sampai finisher dapat memberikan pertumbuhan yang baik dan efisiensi penggunan yang baik.

Kata Kunci: Fase grower, finisher, Tepung kulit kopi.

\begin{abstract}
GROWER PRODUCTION PERFORMANCE USE FLOUR COFFEE PULP AS SUBSTITUTION MATERIALS TO A PARTS OF FINE BRAN ON FEED. Various feed ingredients or waste that have not been utilized for example the skin of coffee fruit can be an alternative feed ingredient source of crude fiber see its content in the skin of the fruit coffee is $33.60 \%$. North Sulawesi, especially Bolaang Mogondow, which is a center of coffee plantation, has a plantation area of 4,097.7 ha, with coffee production reaching 2,135.46 tons of raw material which has not been separated between
\end{abstract}


coffee fruit with its leaves and stems. After the separated coffee fruit obtained as much as 1,288.22 tons per year. Coffee fruit is processed to separate between the seeds and skin after separated obtained by the skin of coffee fruit as much as 448,449 tons. The appearance of production by looking at weight gain, the amount of consumption and the efficiency of feed use is part of the requirement to see the production capability of pigs. The study was conducted for 66 days consisting of 52 days of data collection period and 2 weeks preliminary collecting data aims to determine the effect of coffee skin use as a substitute of some fine bran on the production performance of the grower pigs to the finisher. The study used 16 male and female pigs grower period aged 12-16 weeks descent kinds Yorkshire and Landrace. Randomized block design with four levels of treatment that is $0,25 \%$, $50 \%, 75 \%$ coffee pulp as a partial replacement of fine bran in 4 groups. Differences in body weight is a replication of the study. The result of analysis of variance (ANOVA) showed that the powder of coffee husk as substitute of bran to the weight gain gave real effect ( $P$ $<0.05$ ), the amount of feed consumption did not give real effect $(\mathrm{P}>0.05)$ Feed gave a real effect. The result is the use of coffee leaf powder as a substitute of some fine bran in grower pigs until finisher can provide good growth and efficient use of good feed.

Keywords: Phase grower, finisher, flour coffee skin

\section{PENDAHULUAN}

Peternakan babi merupakan salah satu usaha yang mempunyai peranan penting dalam memacu upaya memperbesar penyedian sumber protein hewani bagi masyarakat walaupun hanya dikonsumsi oleh sebagian masyarakat Indonesia. Penyedian bahan pakan pada usaha peternakan babi merupakan salah satu faktor penentu keberhasilan proses produksi disamping penyediaan bibit unggul dan tatalaksana pemeliharaan termasuk pencegahan penyakit. Dalam upaya penyediaan bahan pakan tersebut para peternak sering diperhadapkan pada masalah kurang tersedianya beberapa bahan pakan yang diakibatkan karena ada bahan pakan yang ketersediaannya tergantung pada musim panen atau juga dalam penggunaannya bersaing dengan ternak lain hingga terjadi fluktuasi harga.

Dedak halus sebagai limbah pertanian merupakan salah satu bahan pakan penyusun ransum ternak yang dapat diberikan sebagai bahan pakan babi fase pertumbuhan pada tingkat inklusi hingga $20 \%$ tanpa mengganggu pertumbuhan (Casas and Stein, 2016). Oleh karena itu usaha mencari dan meneliti bahan lain yang diduga dapat mengganti sebagian atau seluruh dedak halus dalam ransum merupakan salah satu upaya pemecahan bila kekurangan dedak halus di pasaran. Bahan pakan yang dimaksud tentunya mempunyai gizi yang minimal berimbang dengan dedak halus, murah, tidak bersaing dengan kebutuhan manusia serta tidak mengganggu kesehatan ternak yang mengkonsumsinya. 
Tepung kulit kopi cukup potensial untuk digunakan sebagai bahan pakan ternak. Di Sulawesi Utara terdapat beberapa sentra produksi kopi yang tersebar di beberapa daerah, di mana Kabupaten Bolaang Mongondow memiliki produksi kopi yang cukup besar. Potensi limbah kulit biji kopi yang besar ini memberikan peluang yang sangat besar untuk dimanfaatkan sebagai salah satu bahan pakan pengganti sebagian dedak halus dalam pakan ternak babi, karena ketersediaan dedak halus yang fluktuatif seringkali terjadi pada waktu tertentu sulit diperoleh serta mahal di pasaran, maka dilakukanlah usaha dan upaya untuk pencarian bahan pakan alternatif sebagai pengganti dedak halus.

Berdasarkan uraian di atas telah dilaksanakan penelitian melalui suatu percobaan yang bertujuan untuk mengetahui sejauh mana pengaruh penggunaan tepung kulit kopi sebagai pengganti sebagian dedak halus dalam pakan terhadap konsumsi pakan, pertambahan berat badan dan efisiensi penggunaan pakan.

\section{MATERI DAN METODE PENELITIAN}

\section{Tempat dan Waktu Penelitian}

Penelitian ini telah dilaksanakan di Peternakan Babi milik Bapak Jemy
Monintja, berlokasi di Talikuran Utara Kecamatan Kawangkoan Kabupaten Minahasa, 2 minggu pra percobaan sedangkan pengumpulan data mulai tanggal 12 Desember 2015 sampai 3 Febuari 2016.

\section{Materi Penelitian}

Dalam penelitian ini digunakan 16 ekor ternak babi yang sedang tumbuh (11 ekor jantan dan 5 betina) hasil persilangan landrace berumur 12-16 minggu. Kandang percobaan sebanyak 16 unit dan perlengkapan yang digunakan adalah kandang tipe individual berukuran $140 \mathrm{X}$ $90 \times 100 \mathrm{~cm}$ yang dilengkapi dengan tempat makan dengan ukuran 50 X $50 \mathrm{~cm}$ dan tempat minum terbuat dari bulu (bambu).

Perlengkapan lain yang digunakan seperti : timbangan babi kapasitas $300 \mathrm{~kg}$, timbangan ransum ohhaus 5000 gram, kantong plastik, kuas, sendok, slang, sapu lidi, penerangan listrik dan kalero. Selama penelitian pakan yang digunakan hampir semuanya diperoleh dari peternakan di tempat penelitian kecuali tepung kulit kopi diperoleh dari perusahaan kopi di Bolaang Mongondow. Pemberian ransum diberikan ad libitum.

\section{Pakan penelitian}

Bahan-bahan pakan yang digunakan terdiri dari sirad pabrikan, tepung ikan, jagung, dedak halus dan 
tepung kulit buah kopi yang saling mengsubtitusi. Komposisi zat-zat makanan bahan-bahan pakan, formulasi pakan serta kandungan nutrisi ternak percobaan pada penelitian ini penelitian disajikan berturutturut pada Tabel 1, Tabel 2 dan Tabel 3.

Tabel 1. Komposisi Susunan Bahan Pakan Penelitian.

\begin{tabular}{lllll}
\hline Bahan pakan & \multicolumn{3}{c}{ Perlakuan } \\
\cline { 2 - 5 } & R0 & R1 & R2 & R3 \\
\hline Kosentrat & 12,5 & 12,5 & 12,5 & 12,5 \\
Tepung ikan & 12,5 & 12,5 & 12,5 & 12,5 \\
Dedak & 25 & 18,75 & 12,5 & 6,25 \\
Jagung & 50 & 50 & 50 & 50 \\
Kulit Kopi & 0 & 6,25 & 12,5 & 18,75 \\
\hline Total & 100 & 100 & 100 & 100 \\
\hline
\end{tabular}

Tabel 2. Kandungan Zat-Zat Bahan Pakan Penelitian

\begin{tabular}{|c|c|c|c|c|c|c|}
\hline $\begin{array}{l}\text { Komposisi zat-zat } \\
\text { makanan }\end{array}$ & Protein & Energi & SK & Lemak & $\mathrm{Ca}$ & $\mathrm{P}$ \\
\hline Jagung & 8,42 & 3182 & 2,15 & 5,17 & 0,22 & 0,6 \\
\hline Konsentrat & 38 & 2900 & 6 & 4 & 3 & 14 \\
\hline Tepung ikan & 27,49 & 3524 & 2,9 & 8,88 & 2,82 & 5,08 \\
\hline Dedak & 12,9 & 2875 & 11,4 & 0,7 & 0,07 & 1,5 \\
\hline Kulit Kopi & 7,95 & 3619 & 33,6 & 1,3 & 0,21 & 1,08 \\
\hline
\end{tabular}

Ket:*Hasil Analisa Institut Pertanian Bogor (2016)

**Hasil Analisa PT. Cargil Indonesia

Tabel 3. Kandungan Nutrisi Ternak Percobaan

\begin{tabular}{lrrrr}
\hline & $\mathrm{R} 0$ & $\mathrm{R} 1$ & $\mathrm{R} 2$ & $\mathrm{R} 3$ \\
\hline Protein & 15,62 & 15,31 & 15,00 & 14,69 \\
Energi & 3112.75 & 3159,25 & 3205,75 & 3252,25 \\
Serat kasar & 5,04 & 6,43 & 7,81 & 9,20 \\
Lemak & 4,37 & 4,39 & 4,41 & 4,43 \\
$\mathrm{Ca}$ & 0,86 & 0,86 & 0,87 & 0,88 \\
$\mathrm{P}$ & 3,06 & 3,03 & 3,01 & 2,98 \\
\hline
\end{tabular}




\section{Metode penelitian}

Penelitian ini menggunakan Rancangan Acak Kelompok (Steel and Torrie, 1995) dengan 4 macam pakan ( $\mathrm{R}_{0}$, $\left.\mathrm{R}_{1}, \mathrm{R}_{2}, \mathrm{R}_{3}\right)$ sebagai perlakuan dan 4 kelompok ternak babi sebagai ulangan. Setiap kelompok terdiri dari 4 ekor.

Penelitian ini menggunakan 4 perlakuan dan 4 kelompok sebagai ulangan, sehingga jumlah ternak babi yang akan digunakan sebanayak 16 ekor.

Susunan pakan perlakuan adalah sebagai berikut:

$\mathrm{R} 0=$ Dedak halus $25 \%+$ tepung kulit buah kopi $0 \%$

$\mathrm{R} 1=$ Dedak halus $18,75 \%$ + tepung kulit buah kopi $6,25 \%$

R2 = Dedak halus 12,50\% + tepung kulit buah kopi $12,50 \%$

R3 = Dedak halus 6,25\% + tepung kulit buah kopi $18,75 \%$

Kelompok Berat Badan

Kelompok I $=30-37 \mathrm{Kg}$

Kelompok II $=37,5-44 \mathrm{Kg}$

Kelompok III $=44,5-51 \mathrm{Kg}$

Kelompok IV $=51,5-58 \mathrm{Kg}$

\section{Variabel Penelitian}

1. Pertambahan berat badan yaitu jumlah berat (gram), yang diperoleh dari selisih antara berat badan akhir dikurangi berat badan awal pada setiap periode.

2. Konsumsi pakan (gram) per ekor ternak babi per hari yang dihitung dari jumlah pakan yang diberikan dikurangi dengan jumlah pakan sisa.

3. Efisiensi pengggunaan pakan dihitung pada setiap periode berdasarkan perbandingan antara rataan pertambahan berat badan per ekor per hari dengan rataan konsumsi pakan per ekor per hari.

\section{Prosedur Kerja}

Penimbangan Ternak Babi. Sebelum babi ditimbang kalero yang akan digunakan ditimbang terlebih dahulu, kemudian babi dikeluarkan dari kandang individual dan babi dimasukkan kedalam kalero untuk ditimbang.

Pemberian Pakan. Pakan dimasukkan kedalam kantong plastik, ditimbang sesuai dengan kebutuhan dan diberikan dalam waktu bersamaan, sedikit demi sedikit agar tidak tercecer. Pakan diberikan setiap hari secara ad libitum dimulai dari jam 08.00 pagi sesudah kandang dibersihkan. Pakan sisa diambil sebelum diberikan pakan yang baru dan ditimbang setiap hari untuk mendapatkan jumlah sisa hasil konsumsi. 


\section{HASIL DAN PEMBAHASAN}

\section{Pengaruh Penggunaan Tepung Kulit Kopi Terhadap Pertambahan Berat Badan}

Data hasil pengamatan selama penelitian untuk penggaruh penggunaan tepung kulit kopi terhadap pertambahan berat badan dapat dilihat pada Tabel 4 . Rataan pertambahan berat badan yaitu 0,47-0,63. Hasil penelitian ini masih sejalan dengan yang direkomendasikan Siagian (2005) yaitu pertambahan berat badan ternak babi berkisar 0,57-0,64. Dari hasil ini juga menunjukkan bahwa rataan pertambahan berat badan keseluruhan 0,55 per ekor per hari.

Hasil analisis sidik ragam menunjukkan bahwa penggunaan tepung kulit kopi memberikan pengaruh nyata $(\mathrm{P}<0,05)$ terhadap pertambahan berat badan. Hal ini disebabkan kandungan energi dari tepung kulit kopi yang tinggi sehingga menyebabkan terjadi perbedaan dalam pertambahan berat badan. Dilanjutkan dengan uji BNT yang menunjukkan bahwa ransum R0 memberikan pengaruh yang sama jika dibandingkan dengan ransum R1 tetapi berbeda nyata jika dibandingkan dengan ransum R2 dan R3. Tabel rataan menunjukkan bahwa ransum R0 dan R1 memberikan pengaruh lebih baik dibandingkan ransum R2 dan R3. Hasil penelitian Siagian (2005) dilaporkan bahwa pertambahan berat badan babi 0,57-0,64 tidak jauh berbeda dengan ransum R0 dan R1 ini dan lebih baik dari yang dihasilkan oleh ransum R2 dan R3. Dari hasil ini dapat disimpulkan bahwa penggunaan kulit kopi memberikan pengaruh yang baik hanya sampai pada taraf $25 \%$ untuk mengganti dedak halus.

Tabel 4. Rataan pertambahan berat badan (kg/ekor/hari) ternak babi yang diberikan tepung kulit kopi dalam pakan

\begin{tabular}{|c|c|c|c|c|c|c|}
\hline \multirow{2}{*}{ Kelompok } & \multicolumn{4}{|c|}{ Perlakuan } & \multirow{2}{*}{ Total } & \multirow{2}{*}{ Rataan } \\
\hline & RO & R1 & R2 & R3 & & \\
\hline B1 & 0,74 & 0,58 & 0,46 & 0,37 & 2,15 & 0,54 \\
\hline B2 & 0,44 & 0,54 & 0,43 & 0,48 & 1,89 & 0,47 \\
\hline B3 & 0,72 & 0,65 & 0,57 & 0,58 & 2,52 & 0,63 \\
\hline B4 & 0,63 & 0,70 & 0,43 & 0,47 & 2,23 & 0,56 \\
\hline Total & 2,53 & 2,47 & 1,89 & 1,90 & 8,79 & 2,20 \\
\hline Rataan & 0,63 & 0,62 & 0,47 & 0,47 & 8,79 & 0,55 \\
\hline
\end{tabular}


Menurunnya pertambahan berat badan seiring dengan bertambahnya kulit buah kopi karena zat anti nutrisi yang terkandung dalam kulit buah kopi yakni tannin dan kafein yang dapat menghambat pertumbuhan (Molina, 1974 dan Brahman, 1979 dalam Aror, 1989). Kulit buah kopi mengandung 7,8\% tannin dan 2,30 kafein (Anonimous, 2010). Tandi (2010) mengemukakan tannin yang masuk kedalam saluran pencernaan akan terikat dengan protein sehingga sulit dicerna oleh enzim protease mengakibatkan asam-asam amino sedikit terbentuk dan akan mempengaruhi pertumbuhan. Bee (2004), menyatakan bahwa jaringan utama pada tubuh yang mengalami pertumbuhan adalah rangka, otot dan lemak.

\section{Pengaruh Penggunaan Tepung Kulit Kopi Terhadap Konsumsi Pakan}

Hasil pengamatan selama penelitian untuk pengaruh penggunaan tepung kulit kopi terhadap konsumsi pakan tercantum pada Tabel 5. Konsumsi pakan ternak babi per ekor per hari pada penelitian ini adalah $2,19-2,51 \mathrm{~kg}$ dengan rataan umum 2,39 kg/ekor/hari. Jumlah konsumsi pakan pada penelitian ini sejalan dengan rekomendasi sihombing (2006) yaitu $1,5-2,75 \mathrm{~kg}$.

Hasil analisis ragam menunjukkan bahwa pemberian tepung kulit kopi tidak memberikan pengaruh nyata $(\mathrm{P}>0,05)$ terhadap konsumsi pakan. Hal ini disebabkan oleh adanya kafein dan tanin yang terkandung dalam kulit kopi sehingga mempengaruhi tingkat palatabilitas. Penelitian ini sejalan dengan pendapat Sihombing (2006) bahwa jumlah konsumsi pakan dipengaruhi oleh tingkat palatabilitas ransum. Davies (1982) dan Vestergen et al. (1982) menyatakan bahwa jumlah konsumsi ransum antara lain dipengaruhi oleh umur dan ukuran tubuh ternak. Dewi dan Setiohadi (2010) menyatakan bahwa pakan yang mempunyai kandungan nutrien yang relatif sama maka konsumsi pakannya juga relatif sama.

Tabel 5. Rataan Konsumsi Pakan (kg/ekor/hari) ternak babi yang diberikan tepung kulit kopi dalam pakan

\begin{tabular}{|c|c|c|c|c|c|c|}
\hline \multirow[b]{2}{*}{ Kelompok } & \multicolumn{4}{|c|}{ Perlakuan } & \multirow{2}{*}{ Total } & \multirow{2}{*}{ Rataan } \\
\hline & RO & R1 & R2 & R3 & & \\
\hline B1 & 2,30 & 2,14 & 1,61 & 1,99 & 8,04 & 2,01 \\
\hline B2 & 2,03 & 2,32 & 2,18 & 2,48 & 9,01 & 2,25 \\
\hline B3 & 2,66 & 2,61 & 2,56 & 2,63 & 10,46 & 2,61 \\
\hline B4 & 2,76 & 2,98 & 2,44 & 2,69 & 10,87 & 2,71 \\
\hline Total & 9,75 & 10,05 & 8,79 & 9,79 & 38,38 & 9,59 \\
\hline Rataan & 2,43 & 2,51 & 2,19 & 2,44 & 38,38 & 2,39 \\
\hline
\end{tabular}


Palatabilitas tergantung pada rasa, bau, tekstur dan bentuk makanan. Faktor yang mempengaruhi konsumsi ransum yaitu besar dan berat badan, umur, kondisi ternak serta cekaman yang diakibatkan oleh lingkungan, kelembaban, udara, dan sinar matahari. Salah satu aspek yang menentukan tinggi rendahnya kualitas ransum adalah kandungan protein, energi, vitamin, mineral, dan bahan - bahan lain yang menunjang proses biologis (Sinaga dan Martini 2010). Frank et al. (1983) dan Chiba et al. (1991) menyatakan bahwa babi pada periode grower sampai finisher dengan bobot badan 15-110 kg diberikan ransum secara adlibitum. Kandungan energi ransum sendiri akan mengontrol jumlah konsumsi. Walaupun konsumsi dipengaruhi tingkat energi dalam ransum, tetapi keragaman jumlah konsumsi dari hari ke hari juga dapat dipengaruhi oleh ternak itu sendiri.

\section{Pengaruh Penggunaan Kulit Kopi Terhadap Efisiensi Penggunaan Pakan}

Data hasil pengamatan selama penelitian untuk penggaruh penggunaan tepung kulit kopi terhadap efisiensi penggunaan pakan dapat dilihat pada Tabel 6. Efisiensi penggunaan pakan pada penelitian ini adalah 0,19-0,26 dengan rataan umum 0,23 . Hasil penelitian ini lebih rendah dibandingkan dengan direkomendasi NRC (1988), yaitu 0,350,50 .

Hasil analisis sidik ragam menunjukan bahwa penggunaan tepung kulit kopi memberikan pengararuh nyata $(\mathrm{P}<0,05)$ terhadap efisiensi penggunaan pakan. Hal ini disebabkan karena kandungan energy yang ada dalam tepung kulit kopi yang tinggi sehingga menyebabkan terjadinya perbedaan dalam efisiensi penggunaan pakan.

Tabel 6. Rataan efisiensi penggunaan pakan ternak babi yang diberikan tepung kulit kopi dalam pakan

\begin{tabular}{lcccccc}
\hline kelompok & \multicolumn{7}{c}{ Perlakuan } \\
\cline { 2 - 7 } & R0 & R1 & R2 & R3 & Total & Rataan \\
\hline B1 & 0,32 & 0,27 & 0,29 & 0,19 & 1,06 & 0,27 \\
B2 & 0,22 & 0,23 & 0,20 & 0,19 & 0,84 & 0,21 \\
B3 & 0,27 & 0,25 & 0,22 & 0,22 & 0,96 & 0,24 \\
B4 & 0,23 & 0,23 & 0,18 & 0,17 & 0,81 & 0,20 \\
\hline Total & 1,04 & 0,99 & 0,88 & 0,77 & 3,68 & 0,92 \\
\hline Rataan & 0,26 & 0,25 & 0,22 & 0,19 & 3,68 & 0,23 \\
\hline
\end{tabular}


Hasil uji BNT menunjukkan perlakuan R0 (tanpa pengantian) berbeda tidak nyata $(\mathrm{P}>0,05)$ dibandingkan dengan R1 (penggantian 25\% kulit kopi), tetapi berbeda nyata $(\mathrm{P}<0,05)$ dibanding $\mathrm{R} 2$ (penggantian 50\% kulit kopi), dan terhadap R3 (penggantian 75\%) berbeda sangat nyata lebih tinggi. Hasil uji BNT, memberikan indikasi bahwa semakin tinggi level penggunaan kulit buah kopi dalam ransum akan menurunkan efisiensi penggunaan pakan pada babi. Rendahnya efisiensi penggunaan pakan disebabkan oleh adanya zat anti nutrisi dalam kulit buah kopi yaitu kafein dan tannin. Molina et al. (1974) dan Brahman (1979) dalam Aror (1989) menyatakan bahwa kafein dapat menekan pertumbuhan. Tandi (2010) mengemukakan tannin dapat mengikat protein membentuk ikatan kompleks protein tannin sehingga protein tersebut sukar dicerna oleh enzim protease. Tannin juga mempengaruhi metabolism karbohidrat dengan mengikat pati sehingga sukar dicerna oleh enzim amylase.

\section{KESIMPULAN}

Berdasarkan hasil penelitian disimpulkan bahwa kulit kopi dapat dimanfaatkan sebagai bahan pakan pengganti dedak halus sampai taraf $25 \%$ dalam ransum dan baik untuk babi grower.

\section{DAFTAR PUSTAKA}

Anonimous. 2010. Pegolahan Limbah Kopi. https://recyclearea.word pres.com/2010/05/10/ pengolahan limbah kopi [diunduh pada tanggal 20 juni 2015]

Aror, M. 1989. Kulit Kopi Sebagai Pengganti Dedak Halus Dalam Ransum Broiler. Skripsi. Fakultas Peternakan. Unsrat Manado.

Bee, G. 2004. Effect of Early Gestation Feeding, Birth Weigth and Gender of Progeny on Muscle Fiber Characteristics of Pig at Slaughter. Journal of Animal Science, 82 (3): 826-836.

Casas, G.A. and H.H. Stein. 2016. Effects of full fat or defatted rice bran on growth performance and blood characteristics of weanling pigs. Journal of Animal Science 94: 10: 4179-4187

Chiba, L. I., A. J. Lewis dan E. R. Peo. 1991. Amino acid and energy interrelationships in pigs weighing 20 to 50 kilograms: I. Rate and efficiency of weight gain. J. Anim. Sci. 69:694-707.

Dewi, S.H.C. dan J. Setiohadi. 2010. Pemanfaatan tepung pupa ulat sutera (Bombyx mori) untuk pakan puyuh (Coturnix-coturnix Japonica) jantan. Jurnal Agri Sains. Vol.1 (8): 1-6.

Frank, G. R., F. X. Aherne, dan A. H. Jensen. 1983. A study of the relationship between performance and dietary component digestibilities by swine fed different levels of dietary fiber. J. Anim. Sci. 57:645-654. 
NRC, 1988. Nutrient Requirments of Swine, $9^{\text {th }}$ Ed. National Academy Press. Washington, DC.

Rumerung, S, N. 2015. Efek penggunaan konsentrat pabrikan dan buatan sendiri dalam ransum babi starter terhadap efisiensi penggunaan ransum. Jurnal Zootek Vol. 35 (2): 295-301

Siagian, P.H, S. Natasasmita dan P. Silalahi. 2005. Pengaruh substitusi jagung dengan Corn Gluten Feed (CGF) dalam ransum terhadap kualitas karkas babi dan analisis ekonomi. Media Peternakan. Vol.28 (3): 100-108

Sihombing, D.T.H. 1997. Ilmu Ternak Babi. Gadjah Mada University Press. Yogyakarta.
Sihombing, D.T.H. 2006. Ilmu Ternak Babi. Cetakan ke- 2. Gadjah Mada University Press, Yogyakarta.

Sinaga, S dan S. Martini. 2010. Pemberian berbagai dosis Curcuminoid pada ransum babi periode starter dan efisiensi ransum. Jurnal Ilmu Ternak. Vol 1(10): 95-101.

Steel, R.G.D., and J.H. Torrie, 1980. Prinsip dan Prosedur Analitis Suatu Pendekatan Biometrika. Edisi Kedua. Penerbit PT. Gramedia.

Tandi, E. J. 2010. Pengaruh Tanin Terhadap Aktifitas Protease. Seminar Nasional Teknologi Peternakan dan Veteriner. Fakultas Peternakan. Universitas Hasanudin. Makasar. Hal: 567-570. 